\title{
Fungal infections of the small and large intestine
}

\author{
R J Prescott, M Harris, S S Banerjee
}

Abstract

Aims: To study the pathological features of fungal infections affecting the lower intestinal tract (duodenum, small and large bowels).

Methods: Between mid-1981 and mid1991, 14 cases of deep mycotic infections affecting the lower intestinal tract were found among 890 consecutive necropsies on patients with malignant disease treated in a regional cancer centre (incidence $1 \cdot 6 \%$ ). These 14 cases accounted for $54 \%$ of all gastrointestinal fungal infection detected. The relevant clinical, necropsy, histological and microbiological data were reviewed.

Results: Candida spp and Aspergillus spp accounted for all infections. The macroscopic appearances included ulcers of varying configuration, mucosal flecks, sloughed mucous membranes, polypoid masses and segmental lesions. Either organism could produce this range of lesions, but Candida tended to have a mucosal location and Aspergillus was associated with transmural invasion. Combined infections showed Candida in the surface mucosa and Aspergillus hyphae in submucosal vessels with spread into the bowel wall in a radiating pattern. During the final illness, gastroinestinal symptoms and signs were often slight and microbiological investigations were unhelpful.

Conclusions: Variable gross appearances are relevant for endoscopists, particularly lesions which resemble pseudomembranous colitis. Endoscopic biopsy specimens may have a role in antemortem dignosis. Failure to diagnose these infections during life emphasises the importance of necropsy in the clinicopathological audit of deaths in this group of patients.

Fungal infections are increasingly reported as aetiological agents in man, and are associated with increased use of immunosuppressive treatment regimens for malignant diseases and in connection with organ transplantation. Several reviews have emphasised the importance of fungal infections in such patients. ${ }^{1-4}$ With the advent of AIDS the incidence of common and uncommon infective pathogens, including fungi which may affect the gastrointestinal tract $^{5}$ has correspondingly risen.

In routine necropsy practice the incidence of systemic mycotic infections was reported as being 1-2\% ${ }^{6}$; however, in studies based on selected "high risk" patients who were immunocompromised the incidence was about $20 \%$. $^{7}$ A recent review of invasive aspergillosis revealed an incidence of $1.4 \%$ in 2315 consecutive necropsies, but in the immunocompromised group it approached $11 \%{ }^{8} \mathrm{~A}$ necropsy study of 54 immunocompromised patients with mycotic infection (as a result of chemotherapy or bone marrow transplantation) showed either localised upper and lower gastrointestinal tract or respiratory tract infection, or disseminated infections including both these sites; the principal organisms were Candida and Aspergillus species. ${ }^{3}$

Because histopathological reviews of mycotic infections of the alimentary tract, particularly the lower intestinal tract, are sparse, we decided to review all the necropsy cases between mid-1981 and mid-1991 at the Christie Hospital and Holt Radium Institute, which specialises in the treatment of malignant neoplasms, to catalogue these lesions.

\section{Methods}

Between mid-1981 and mid-1991, 64 cases of deep mycotic infections were found in 890 consecutives necropsies (incidence $7 \cdot 2 \%$ ). Among these there were 26 gastrointestinal infections, with 12 cases affecting the upper gastrointestinal tract (mouth, oesophagus, and stomach) alone, seven the lower intestinal tract (duodenum, jejunum, ileum and colon) alone, and seven both sites. These last 14 cases are the subject of this report.

In the lower intestinal group the following variables were assessed from the clinical records: the age and sex of the patient; the underlying neoplastic condition; and the treatment administered. During the final illness any gastrointestinal symptoms and signs, drug intake, including antibiotics and steroids, the white cell count, results of fungal serological tests and blood and stool cultures were recorded. The degree of the clinician's awareness of an intestinal infection was assessed as well as the clinically perceived mode of death.

The necropsy reports revealed information about the gross appearance and distribution of the lesions together with the extent of other organ disease. An assessment of the degree to which the intestinal disease contributed to death was made. Necropsy stool cultures were sent in three cases. Microscopic examination was undertaken on formalin fixed, paraffin wax embedded sections stained with haematoxylin and eosin, periodic-acid Schiff (PAS) with and
Correspondence to: Dr M Harris

Accepted for publication 24 February 1992 
Table 1 Clinical details of presenting condition and treatment

\begin{tabular}{|c|c|c|c|c|}
\hline Case No & Age & Sex & Underlying condition & Treatment \\
\hline 1 & 73 & F & $\begin{array}{l}\text { Breast carcinoma and nodular sclerosing } \\
\text { Hodgkin's disease }\end{array}$ & Mastectomy, CVPP \\
\hline 2 & 18 & $\mathbf{M}$ & Seminoma & CVPP, e, cis \\
\hline 3 & 15 & $\mathbf{F}$ & Hodgkin's disease mixed cellularity & VAP MVPP \\
\hline 4 & 58 & $\mathbf{F}$ & Breast carcinoma & Mastectomy, Radiation, VAC, pred \\
\hline 5 & 63 & $\mathbf{F}$ & $\begin{array}{l}\text { Myelodysplasia } \\
\text { Refractory anaemia with excess blasts in } \\
\text { transformation }\end{array}$ & DAT \\
\hline 6 & 62 & F & Myelodysplasia & DAT \\
\hline 7 & 43 & $M$ & Chronic myeloid leukaemia and blast crisis & Bone marrow transplant 4 years prior to \\
\hline 8 & 58 & F & $\begin{array}{l}\text { Non-Hodgkin's lymphoma, centroblastic/ } \\
\text { centrocytic Diabetes mellitus }\end{array}$ & $e, a, i, h$, Pred \\
\hline 9 & 60 & $\mathbf{M}$ & $\begin{array}{l}\text { Non-Hodgkin's lymphoma, lymphoblastic } \\
\text { Diabetes mellitus }\end{array}$ & CHOP, EVAM, pred \\
\hline $\begin{array}{l}10 \\
11\end{array}$ & $\begin{array}{l}66 \\
67\end{array}$ & $\mathbf{F}$ & $\begin{array}{l}\text { Signet ring adenocarcinoma of stomach } \\
\text { Non-Hodgkin's lymphoma, } \\
\text { centroblastic/centrocytic }\end{array}$ & $\begin{array}{l}\text { e, a, cis } \\
\text { VAP, CVPP } \\
\text { Abdominal irradiation }\end{array}$ \\
\hline 12 & 50 & $\mathbf{M}$ & $\begin{array}{l}\text { Non-Hodgkin's lymphoma, } \\
\text { lymphoblastic }\end{array}$ & $\begin{array}{l}\text { CHOP, B } \\
\text { VAPECB }\end{array}$ \\
\hline 13 & 69 & $M$ & $\begin{array}{l}\text { Non-Hodgkin's lymphoma, } \\
\text { T cell pleomorphic large cell subtype }\end{array}$ & VAPECB \\
\hline 14 & 69 & $\mathbf{M}$ & $\begin{array}{l}\text { Non-Hodgkin's lymphoma, diffuse } \\
\text { centroblastic of thyroid } \\
\text { Diabetes mellitus }\end{array}$ & VAP pred \\
\hline
\end{tabular}

Key:

CVPP = chlorambucil, vinblastine, procarbazine, prednisolone; $\mathrm{e}=$ etoposide; cis = cisplatin; VAP = vincristine, adriamycin, cisplatin; MVPP = mustine, vinblastine, procarbazine, prednisolone; VAC = vincristine, adriamycin, cyclophosphamide; pred $=$ prednisolone; DAT $=$ daunorubicin, cytosine arabinoside, 6 -thioguanine; $a=$ adriamycin; $i=$ ifosfamide; $\mathrm{h}=$ hydroxyurea; CHOP = cyclophosphamide, adriamycin, vincristine, prednisolone; EVAM = etoposide, vincristine, adriamycin, methotrexate; $\mathrm{B}$ = bleomycin; VAPECB = vincristine, adriamycin, prednisolone, etoposide, cisplatin, belomycin.

without diastase, Grocott's methenamine silver stain, and the Gram stain. The sections were seen by two pathologists without prior knowledge of the clinical or necropsy data. The fungi were all classified confidently on morphological grounds as either Candida or Aspergillus sp.

Because of the high degree of agreement between the pathologists, it was not felt necessary to confirm the findings by immunohistochemical or lectin histochemical techniques. Candida organisms were characterised by blastospores and pseudohyphae with budding forms and Aspergillus organisms by regular septate hyphae which exhibited dichotomous branching.'

\section{Results}

CLINICAL DATA

Table 1 shows the relevant clinical details. All patients had advanced malignant disease; eight had malignant lymphoma (two Hodgkin's dis- ease, and six non-Hodgkin's lymphoma), three cases had leukaemia and four cases had nonhaematological malignancies (case 1 had a double malignancy). The time span from diagnosis to death ranged from two months to eight years. All patients had received more than one course of an appropriate chemotherapeutic regimen. Steroids were administered to 11 patients in high doses during the final illness. Two patients had received radiotherapy, with abdominal irradiation in one case (case 11).

Table 2 shows relevant details of the final illness which took no more than 16 days. Gastrointestinal symptoms and signs were variable and ranged from non-existent in one case, mild in seven cases, and severe in six cases. Oral thrush was seen in four cases and alerted the clinician to the possibility of a more serious intestinal infection. All the patients were feverish, although the causes of this were multifactorial. Various antibiotics were given and six patients received specific antifungal

Table 2 Clinical details of final illness

\begin{tabular}{|c|c|c|c|c|c|}
\hline \multirow[b]{2}{*}{ Case No } & \multirow[b]{2}{*}{ Gastrointestinal symptoms/signs } & \multirow[b]{2}{*}{ Antibiotics } & \multirow[b]{2}{*}{ Lowest WCC } & \multicolumn{2}{|l|}{ Microbiology cultures } \\
\hline & & & & $\overline{\text { Blood }}$ & Faeces \\
\hline $\begin{array}{l}1 \\
2 \\
3 \\
4 \\
5 \\
6\end{array}$ & $\begin{array}{l}\text { Melaena } \\
\text { Tenderness/pain/diarrhoea and vomiting/melaena } \\
\text { Oral thrush/herpes/abdominal distension } \\
\text { Slight diarrhoea } \\
\text { Melaena } \\
\text { Tenderness/distension/diarrhoea and vomiting }\end{array}$ & $\begin{array}{l}\mathrm{n}, \mathrm{p}, \mathrm{v}, \mathrm{me} \\
\mathrm{n}, \mathrm{ceft} \\
\text { cefu, g, co, ac, mi } \\
\mathrm{n}, \mathrm{p} \\
\mathrm{n}, \mathrm{v} \\
\text { me, am }\end{array}$ & $\begin{array}{l}0.5 \\
0 \cdot 5 \\
0 \cdot 1 \\
0 \cdot 1 \\
0 \cdot 1 \\
0 \cdot 2\end{array}$ & $\begin{array}{l}\text { NG } \\
\text { Gram negative bacilli } \\
S \text { viridans } \\
P \text { s aeruginosa } \\
E \text { coli } \\
\text { Coagulase negative } \\
\text { Staphylococcus species }\end{array}$ & $\begin{array}{l}\text { NG } \\
\text { NG } \\
\text { NG } \\
\text { NG } \\
\text { Ps maltophila } \\
\text { NG }\end{array}$ \\
\hline $\begin{array}{r}7 \\
8 \\
9 \\
10 \\
11 \\
12 \\
13 \\
14\end{array}$ & $\begin{array}{l}\text { None } \\
\text { Mild diarrhoea } \\
\text { Tenderness/diarrhoea/melaena } \\
\text { Oral thrush } \\
\text { Tenderness/distension/melaena/abdominal mass } \\
\text { Oral thrush } \\
\text { Tenderness/mild diarrhoea } \\
\text { Oral thrush/mild diarrhoea }\end{array}$ & $\begin{array}{l}\text { n, p, v, e, ceft, co, am } \\
\text { n, ci, } \\
\text { n, p, ci } \\
\text { n, p, f } \\
\text { n cefu, ci } \\
\text { n, v, i, ceft } \\
\text { n, p } \\
\text { f, g, ny, k }\end{array}$ & $\begin{array}{l}0 \cdot 1 \\
0 \cdot 1 \\
0 \cdot 1 \\
0 \cdot 2 \\
0 \cdot 1 \\
0 \cdot 1 \\
0 \cdot 1 \\
0 \cdot 5\end{array}$ & $\begin{array}{l}\text { NG } \\
E \text { coli } \\
\text { NG } \\
E \text { coli, } S \text { aureus, } S \text { mitis } \\
\text { NG } \\
\text { NG } \\
\text { NG } \\
E \text { coli }\end{array}$ & $\begin{array}{l}\text { NG } \\
\text { NG } \\
\text { Sfaecalis } \\
\text { NG } \\
\text { Proteus species } \\
\text { Klebsiella aerogenes } \\
\text { NG } \\
\text { NG }\end{array}$ \\
\hline
\end{tabular}

Key: $=$ white cell count $\left(\times 10^{9} /\right) ; \mathrm{n}=$ netilmicin; $\mathrm{p}=$ piperacillin; $\mathrm{v}=$ vancomycin; $\mathrm{me}=$ metronidazole; ceft $=$ ceftazidime; cefu $=$ cefuroxime; $\mathrm{g}=$ gentamicin; co = cotrimoxazole; ac = acyclovir; $\mathrm{mi}=$ miconazole; $\mathrm{e}=$ erythromycin; am $=$ amphotericin; ci = ciprofloxacin; $\mathrm{k}=\mathrm{ketoconazole}$ $\mathrm{f}=$ flucloxacillin $; \mathrm{i}=\mathrm{itraconazole} ; \mathrm{ny}=$ nystatin; $\mathbf{N G}=$ No growth. 
Table 3 Necropsy findings

\begin{tabular}{|c|c|c|c|c|c|}
\hline \multirow[b]{2}{*}{ Case No } & \multirow[b]{2}{*}{$\begin{array}{l}\text { Other organs } \\
\text { affected }\end{array}$} & \multicolumn{2}{|l|}{ Macroscopic findings } & \multicolumn{2}{|c|}{ Microscopic findings } \\
\hline & & Small bowel & Large bowel & $\begin{array}{l}\text { Transmural } \\
\text { infarction }\end{array}$ & Angioinvasion \\
\hline \multicolumn{6}{|c|}{ Candida organisms: } \\
\hline 1 & $\begin{array}{l}\text { Lungs } \\
\text { Oesophagus }\end{array}$ & $\begin{array}{l}\text { Mucosal flecks } \\
\text { Irregular ulcers }\end{array}$ & $\begin{array}{l}\text { Mucosal flecks resembling } \\
\text { pseudo-membranous colitis } \\
\text { Irregular ulcers }\end{array}$ & - & - \\
\hline 2 & None & $\begin{array}{l}\text { Matted ileal loops forming bloody } \\
\text { mass Peritonitis }\end{array}$ & Normal & + & + \\
\hline 3 & Stomach & $\begin{array}{l}\text { fejunum and ileum } \\
\text { segmental infarction with ulcers and } \\
\text { bloody masses }\end{array}$ & $\begin{array}{l}\text { Right side colon } \\
\text { segmental infarction with poly- } \\
\text { poid masses }\end{array}$ & + & + \\
\hline 4 & Lungs & $\begin{array}{l}\text { fejunum small ulcers and haemorrhag- } \\
\text { ic nodules } \\
\text { Ileum } 2 \text { segmental lesions ( } 20 \text { and } \\
6 \mathrm{~cm} \text { long) with ulcers and bloody } \\
\text { membranes }\end{array}$ & Normal & - & - \\
\hline \multicolumn{6}{|c|}{ Aspergillus organisms: } \\
\hline 5 & $\begin{array}{l}\text { Lungs } \\
\text { Liver } \\
\text { Spleen }\end{array}$ & $\begin{array}{l}\text { fejunum multiple segmental } \\
\text { lesions with haemorrhagic } \\
\text { ulceration }\end{array}$ & Normal & + & + \\
\hline 6 & None & $\begin{array}{l}\text { Distal ileum shallow ulcers of varying } \\
\text { shape and size including linear ul- } \\
\text { cers }\end{array}$ & $\begin{array}{l}\text { Similar lesions with infarction and } \\
\text { pelvic peritonitis }\end{array}$ & + & + \\
\hline 7 & $\begin{array}{l}\text { Lungs } \\
\text { Oesphagus }\end{array}$ & $\begin{array}{l}\text { Yejunum } \\
\text { mucosal flecks }\end{array}$ & $\begin{array}{l}\text { Transverse colon } \\
\text { mucosal flecks resembling } \\
\text { pseudo-membranous colitis }\end{array}$ & - & - \\
\hline 8 & Lungs & $\begin{array}{l}\text { Proximal ileum } \\
\text { necrotic mucosal plaques with matted } \\
\text { ileal loops }\end{array}$ & Normal & + & + \\
\hline 9 & Oesophagus & $\begin{array}{l}\text { fejunum extensive mucosal sloughing. } \\
\text { Ileum oval ulcers in longitudinal axis }\end{array}$ & $\begin{array}{l}\text { Right sided colon mucosal sloughing } \\
\text { and oval ulcers }\end{array}$ & (No fungi s & onic lesions) \\
\hline \multicolumn{6}{|c|}{ Combined Candida and Aspergillus organisms: } \\
\hline 10 & $\begin{array}{l}\text { Lungs } \\
\text { Spleen }\end{array}$ & Normal & $\begin{array}{l}\text { Transverse colon } \\
\text { segmental infarction }\end{array}$ & + & + \\
\hline 11 & Lungs & $\begin{array}{l}\text { Multiple ulcers of linear and serpigi- } \\
\text { nous type Pseudomembranes }\end{array}$ & Normal & + & + \\
\hline 12 & $\begin{array}{l}\text { Lungs } \\
\text { Liver } \\
\text { Brain } \\
\text { Oesophagus }\end{array}$ & $\begin{array}{l}\text { Fejunum tumour-like } \\
\text { ulcerated intraluminal } \\
\text { polypoid mass }(4 \times 5 \mathrm{~cm})\end{array}$ & Normal & + & + \\
\hline 13 & $\begin{array}{l}\text { Oesophagus } \\
\text { Stomach }\end{array}$ & $\begin{array}{l}\text { Scattered oval ulcers in } \\
\text { transverse axis, some circumferen- } \\
\text { tial }\end{array}$ & Surface bloody exudate & $\stackrel{+}{\text { (No fungi } i}$ & + \\
\hline 14 & $\begin{array}{l}\text { Lungs } \\
\text { Stomach }\end{array}$ & $\begin{array}{l}\text { Duodenum multiples small } \\
\text { ulcers } \\
\text { fejunum segental lesion ( } 30 \mathrm{~cm} \text { long) } \\
\text { with ulceration }\end{array}$ & Normal & + & + \\
\hline
\end{tabular}

treatment. The rationale for giving these agents included evidence of a systemic mycosis at other sites, notably the lungs in two cases, a high degree of clinical suspicion in two cases, and the use of a standard protocol in febrile patients with acute leukaemia (two cases). During the final illness all patients had severe neutropenia with leucocyte counts generally below $0.1 \times 10^{9} /$. The clinical impression of the mode of death included septicaemia in 12 cases of which one was thought to contain a fungal component (case 7).

PATHOLOGICAL DATA

Table 3 shows the necropsy details. Other organ pathology was seen in 12 cases; five cases involved the lungs alone or with other organs except the gastrointestinal tract, three cases involved the upper gastrointestinal tract alone, and four cases both these sites. Of the 14 lower intestinal tract infections, nine cases affected the small bowel alone, one case involved the colon alone, and four both sites. In four cases Candida alone was found, in five Aspergillus alone, and in five both organisms were identified in the same lesions.

Macroscopically the lesions comprised ulcers, mucosal flecks, sloughed mucous membranes, polypoid masses and segmental lesions (fig 1). The ulcers were of variable configura- tion including elliptical forms transverse and longitudinal to the bowel axis, serpiginous ulcers, linear ulcers and extensive ulcers with irregular margins (fig 2). Segmental lesions were found in five cases: of these, four cases showed transmural infarction, and one case was due to Candida infection limited to the mucosa alone (case 4). In the four cases of segmental infarction, two involved the small bowel alone, one the colon alone, and one both sites. One case was due to Candida alone, one to Aspergillus alone, and two to both organisms in the same lesions (fig 3). Mucosal flecks were seen in two cases; one was associated with Candida and the other with Aspergillus organisms admixed with fibrinous exudate.

Of the nine cases with Candida infection, five had coexistent infections in the upper gastrointestinal tract. Of the four pure Candida lesions, two were limited to the surface mucosa and submucosa, the other two showed extensive angioinvasion with transmural infarction including one with peritonitis producing an inflammatory ileal mass (case 2). In the five cases of combined infection the Candida organisms were located only in the surface necrotic debris.

Of the 10 cases with Aspergillus infection, seven had coexistent lung lesions. Nine of the Aspergillus infections showed transmural 


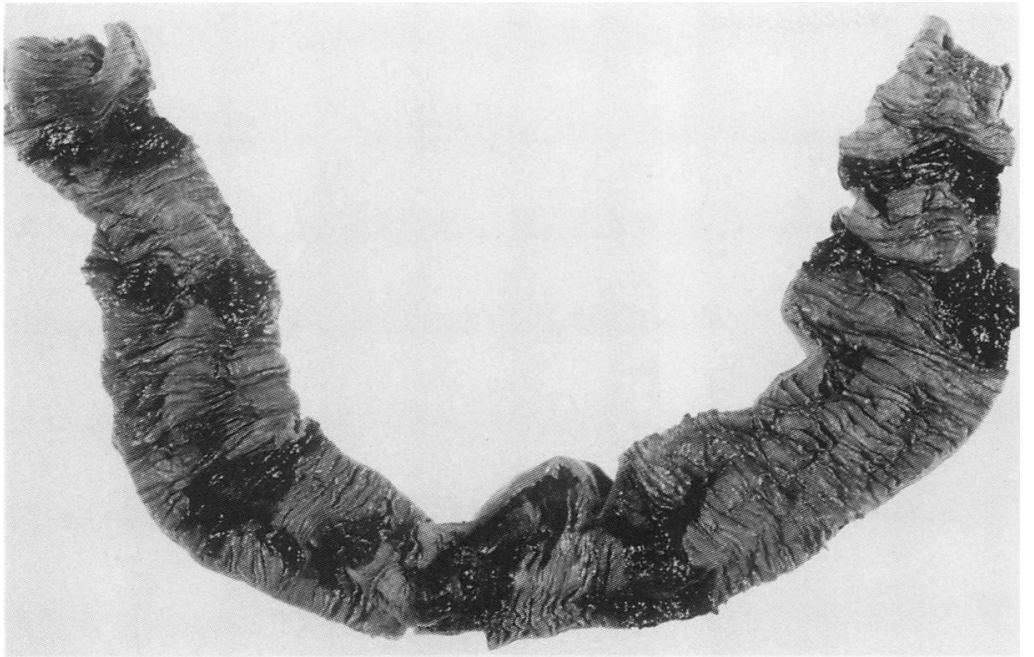

Figure 1 Small bowel showing several short segmental necrotic lesions with irregular margins (case 5).

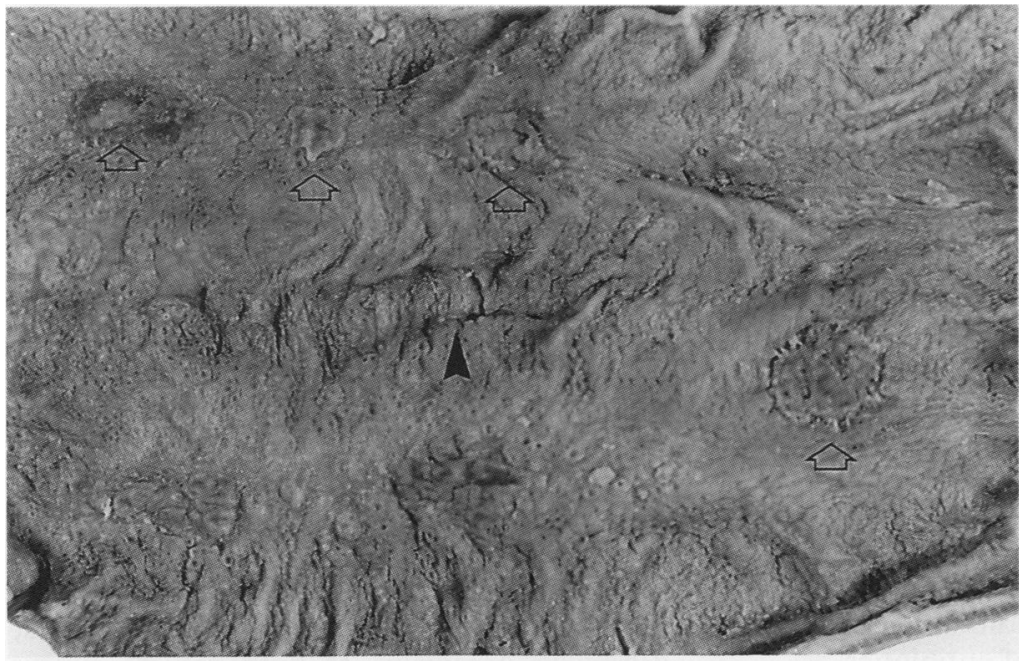

Figure 2 Large bowel mucosa showing several round/oval shaped ulcers (arrows) and a linear ulcer (arrowhead) (case 6).

infarction characterised by numerous hyphal elements, admixed with fibrin thrombi located in the submucosal vessels, with spread into the surrounding tissues in a radial manner (fig 4). The remaining case showed hyphal elements limited to the mucosal surface alone with no evidence of angioinvasion (case 7).

In keeping with the impaired immune competence of the patients, there was a poor, if any, mixed inflammatory cell response. No granulomas were seen. The Splendore-Hoeppli phenomenon, ${ }^{10}$ an immunological reaction, was seen in two cases of Aspergillus infection (fig 5). It is characterised by the deposition of an eosinophilic proteinaceous precipitate, believed to be antigen-antibody complexes, outling the hyphal walls. These deposits have been described before in Aspergillus infections. ${ }^{11}$

MICROBIOLOGICAL DATA

None of the antemortem blood cultures grew fungi and eight cases grew bacterial organisms, mostly of Gram negative species. Specific serological tests for fungi were performed in four cases but none showed significant rising titres. None of the antemortem faecal cultures grew fungi, but four cases confirmed pathogenic Gram negative organisms (table 2). Three necropsy faecal samples were submitted for analysis and two grew fungal organisms which corresponded with the histological morphology (cases 1 and 6).

\section{Discussion}

In 64 immunocompromised patients with deep fungal infections we found that $41 \%$ had gastrointestinal infection, with $22 \%$ affecting the lower part of the tract. Other studies have reported a much lower overall gastrointestinal infection rate of $9-17 \%$ in such patients, ${ }^{1213}$ but others have found comparable figures including a similar high proportion of lower gastrointestinal tract disease. ${ }^{814}$ In agreement with other studies ${ }^{3814} 12$ of our 14 cases had fungal infections with similar organisms elsewhere, either in the upper gastrointestinal tract or lungs. In our study the lower intestinal tract was affected in $54 \%$ of all gastrointestinal tract fungal infections, emphasising how commonly affected this site is.

The organisms found in our study were either Aspergillus or Candida. In a review of alimentary tract mycoses published in 1969, Candida and Mucor were considered the major pathogens and Aspergillus a minor pathogen, but a more recent review agrees with our findings. ${ }^{3}$ Infections with Candida and $A$ spergillus organisms at differing anatomical sites including the lungs, brain, liver and gastrointestinal tract are well recognised, ${ }^{1516}$ but combined infections affecting the intestine at the same site in the maner we have described are only mentioned in one review of the subject. ${ }^{14}$

Intestinal pathology in disseminated aspergillosis has been reported, ${ }^{814151718}$ but the morphological descriptions of the lesions are scanty and none describes solitary or multifocal infarcted bowel segments with the well demarcated margins that we observed. All of the infarcted lesions, irrespective of gross morphology, were associated with vascular occlusion, mostly by Aspergillus organisms, apart from two cases involving Candida. This is clearly important in the pathogenesis of the infarction but it is uncertain if the vascular colonisation is embolic from a distant site (such as the lungs) or is due to local invasion following mucosal infection. The latter mechanism most probably applies to Candida infections.

Intestinal Candida infections were mostly limited to the mucosa/submucosa, particularly in the combined infections where the organisms probably preferentially colonise the previously infarcted bowel. Previous descriptions of pure intestinal Candida lesions are similar to our own observations ${ }^{1519}$ including bowel wall perforation and peritonitis. ${ }^{19}$

The macroscopic appearances fell into five categories: ulcers; mucosal flecks; sloughed mucous membranes; polypoid masses; and segmental lesions, none of which was specific 
Figure $3(A-B)$ : Candida organisms on the surface of the infarcted bowel mucosa with Aspergillus hyphae in the underlying mucosa and submucosa (Grocott's methenamine silver) (case 12). The asterisk shows muscularis mucosae.

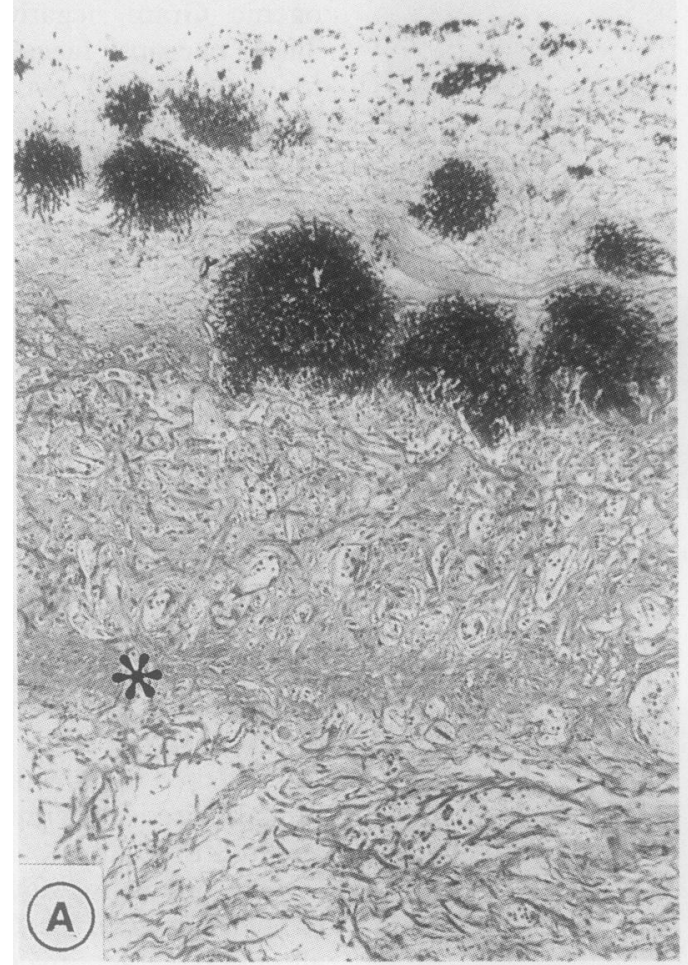

for either organism. These findings may be diagnostically important to endoscopists as well as pathologists. Discrete ulcers may resemble those described in typhoid fever, tuberculosis, and inflammatory bowel disease. The mucosal flecks could be mistaken for pseudomembranous colitis and could present a diagnostic trap because this group of patients is prone to develop this condition because of the frequent administration of antibiotics.

The diagnosis of deep mycotic infections during life is notoriously difficult ${ }^{20}$ and pre-

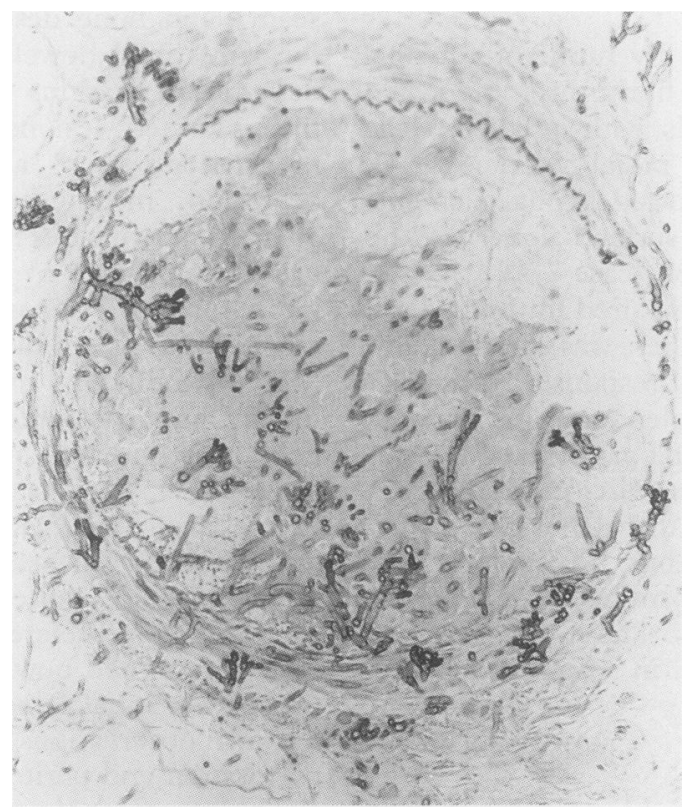

Figure 4 Aspergillus organisms showing angioinvasion (Grocott's methenamine silver).

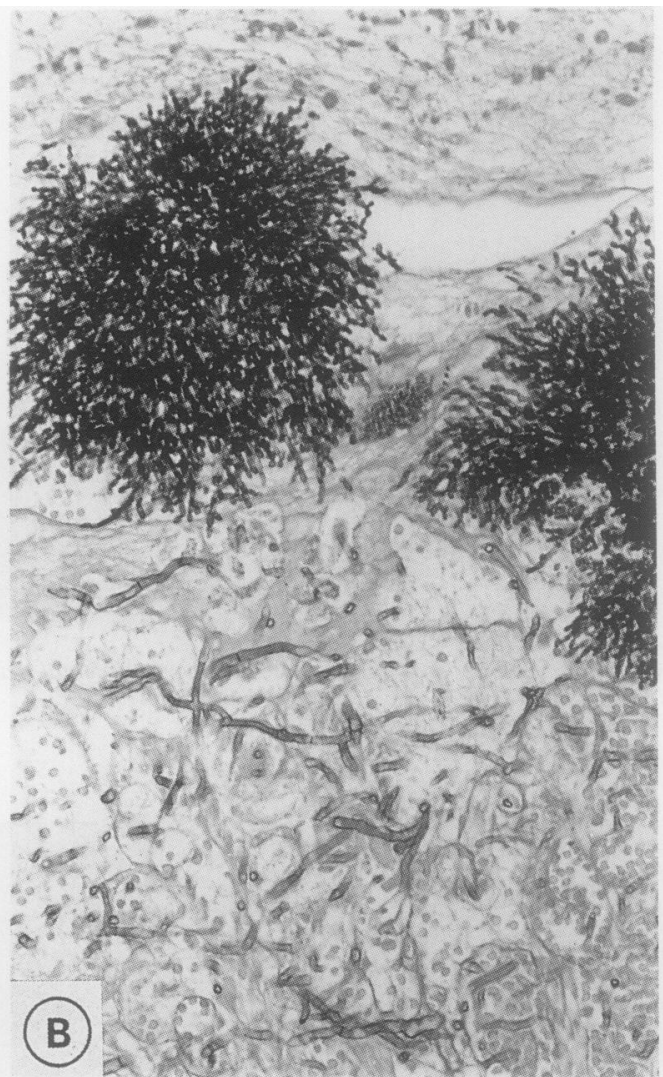

vious reports quote detection rates of $3 \cdot 5 \%{ }^{21}$ and $25 \% .{ }^{22}$ In our study antemortem microbiological investigations failed to detect intestinal fungal growth in any case. A high index of clinical suspicion is therefore needed. Endoscopic examination with biopsy specimens or brushings of lesions should theoretically yield diagnostic information. Brushings for cytology could detect Candida and, in some cases, Aspergillus organisms as both can be superficially located in the lesions. However, in those cases where Aspergillus organisms are present in

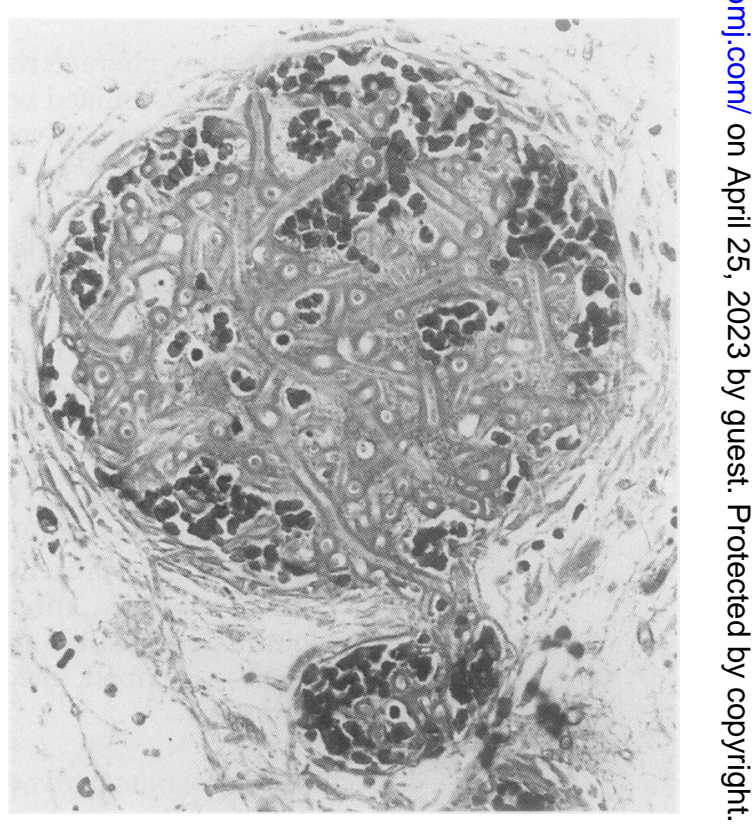

Figure 5 Aspergillus organisms demonstrating the Splendore-Hoeppli phenomenon. Note thickened hyphal walls produced by the deposition of immunological complexes. 
deeper tissues, a biopsy specimen is more likely to be diagnostic.

In 12 cases the clinical diagnosis of sepsis was deemed contributory to death, but only in one case was a fungal agent recognised. The pathologist agreed that sepsis played a major part in the cause of death and that fungaemia was contributory in 10 cases. In case 11 fatal gastrointestinal haemorrhage was caused by an unsuspected combined Candida and Aspergillus jejunal infection.

Our findings emphasise the value of necropsy in studying such infections, and dissection of the bowel at necropsy, although unpleasant, should be carried out routinely especially in immunocompromised patients. Submitting specimens for fungal culture in suspected cases is recommended because correlation with histology and a more precise classification of the organism can be achieved. We found the use of histological special stains valuable in demonstrating the presence of fungi, particularly in the infarcted zones where necrotic debris may obscure the underlying pathology. Failure to perform these procedures will result in an underestimation of the incidence of intestinal fungal infections and hamper further study of the pathology of these infections.

\footnotetext{
1 Scroggs MW, Wolfe JA, Bollinger RR, et al. Causes of death in renal transplant recipients. A review of autopsy findings from 1966 through 1985. Arch Pathol Lab Med from 1966 th

2 Stein DK, Sugar AM. Fungal infections in the immunocom-
}

promised host. Diagn Microbiol Infect Dis 1989;12(Suppl):221S-8S

3 Brocheriou C, Badillet G, Gluckman E, et al. Mycotic infection in immunosuppressed patients. An anatomopathologic study. Ann Pathol 1990;10:99-108.

4 Brown AE. Overview of fungal infections in cancer patients. Semin Oncol 1990;17(Suppl 6):2-5.

5 Rotterdam H, Sommers SC. Alimentary tract biopsy lesions in the acquired immune deficiency syndome. Pathology 1985;17:181-92.

6 Smith JMB. Mycoses of the alimentary tract. Gut 1969;10:1035-40.

7 Pedraza MA. Mycotic infections at autopsy. A comparative study of 162 cases. Am f Clin Pathol 1969;51:470-6.

8 Boon AP, O'Brien DO, Adams DH. Ten year review of invasive aspergillosis detected at necropsy. $f$ Clin Pathol 1991;44:452-4.

9 Anthony PP. A guide to the histological identification of fungi in tissues. $₹$ Clin Pathol 1973;26:828-31.

10 Smith JH, von Lichtenberg F. The Hoeppli phenomenon in Schistosomiasis: II. Histochemistry. Am $\boldsymbol{J}$ Pathol 1967;50:993-1007.

11 Spencer H. Pulmonary aspergillosis. In: Pathology of the Lung. 2nd edn. New York: Pergamon Press, 1968:280-90.

12 Atkinson JB, Connor DH, Robinowitz M, McAllister HA, Virmani R. Cardiac fungal infections: Review of autopsy findings in 60 patients. Hum Pathol 1984;15:935-42.

13 Mangham DC, Lucas SB. Abstract: Deep fungal infections in malignant disease. $₹$ Pathol 1991;163:158.

14 Young RC, Bennett JE, Vogel CL, Carbone PP, DeVita VT. Aspergillosis. The spectrum of the disease in 98 patients. Medicine (Balt) 1970;49:147-73.

15 Rosen PP. Opportunistic fungal infections in patients with neoplastic diseases. Pathol Annu 1976;11:255-315.

16 Hutter RVP, Lieberman PH, Collins HS. Aspergillosis in a cancer hospital. Cancer 1964;17:747-56.
catter RVP, Lieberman PH, Collins HS.

17 Case Record of the Massachusetts General Hospital No 37. $N$ Engl f Med 1976;2939:608-14.

18 Tan KK, Sugai K, Leong TK. Disseminated aspergillosis. Am $\mathcal{F}$ Clin Pathol 1966;45:697-703.

19 Eras P, Goldstein MJ, Sherlock P. Candida infection of the gastrointestinal tract. Medicine 1972;51:367-79.

20 Maksymiuk AW, Thongprasert S, Hopfer $R$, et al. Systemic candiasis in cancer patients. Am $¥$ Med 1984;77:20-7.

21 DeGregorio MW, Lee WM, Linker CA, et al. Fungal infections in patients with acute leukaemia. $A m$ f Med 1982;73:543-8.

22 Myerowitz RL. The pathology of opportunistic infections with pathogenetic, diagnostic and clinical correlations. New York: pathogenetic, diagnosic 